\title{
Legislative scrutiny, co-ordination and the Social Security Advisory Committee: from system coherence to Scottish devolution
}

McKeever, G. (2016). Legislative scrutiny, co-ordination and the Social Security Advisory Committee: from system coherence to Scottish devolution. Journal of Social Security Law, 3, 126-149.

https://doi.org/10.2139/ssrn.3523935

Link to publication record in Ulster University Research Portal

Published in:

Journal of Social Security Law

Publication Status:

Published online: 31/12/2016

DOI:

http://dx.doi.org/10.2139/ssrn.3523935

\section{Document Version}

Author Accepted version

\section{General rights}

Copyright for the publications made accessible via Ulster University's Research Portal is retained by the author(s) and / or other copyright owners and it is a condition of accessing these publications that users recognise and abide by the legal requirements associated with these rights.

\section{Take down policy}

The Research Portal is Ulster University's institutional repository that provides access to Ulster's research outputs. Every effort has been made to ensure that content in the Research Portal does not infringe any person's rights, or applicable UK laws. If you discover content in the Research Portal that you believe breaches copyright or violates any law, please contact pure-support@ulster.ac.uk. 
This is a pre-copyedited, author-produced version of an article accepted for publication in the Journal of Social Security Law following editorial review. The definitive published version (Gráinne McKeever, "Legislative scrutiny, co-ordination and the Social Security Advisory Committee: from system coherence to Scottish devolution" (2016) 23(3) JSSL 126) is available online on Westlaw UK or from Thomson Reuters DocDel service.

This is the accepted version of the following article: "Legislative scrutiny, co-ordination and the Social Security Advisory Committee: from system coherence to Scottish devolution" which has been published in final form in Journal of Social Security Law 2016 (3): 126-149. This article may be used for non-commercial purposes.

\title{
Legislative scrutiny, co-ordination and the Social Security Advisory Committee: from system coherence to Scottish devolution
}

\author{
Gráinne McKeever*
}

\begin{abstract}
:
This article examines the parliamentary processes available to scrutinise draft social security regulations in the UK, highlighting the democratic deficit that exists between executive power and parliamentary authority, and reviewing the unique scrutiny function of the UK Social Security Advisory Committee. The article explores the development of devolved social security powers in Northern Ireland and Scotland and the oversight gap that is now emerging between devolved and reserved powers, with the potential for unintended adverse consequences arising for claimants moving between the different systems within the UK. The article considers the oversight options that might be developed to include independent and expert oversight of devolved social security provision in Scotland, focusing on the need to enable system coherence and fairness in the treatment of claimants, regardless of their geographical circumstances.
\end{abstract}

\section{Introduction}

As the United Kingdom continues to spin on its constitutional axis, the devolution of social security has generated some new constitutional revolutions. In Northern Ireland, the stalled Welfare Reform Bill acted as the lightning rod for political turmoil and the ensuing threat of constitutional crisis. For Scotland, the authority to exercise autonomy, short of independence, through a tailored system of social security was a central focus of intergovernmental discussions on the Scotland Act 2016. In England and Wales, where there is no devolutionary power over social security, the focus instead has been on localisation, with control (if not matching budgets) of some social security provision moving from central government to local authorities, and with considerable local discretion attached to the priorities dictating disbursement. ${ }^{1}$ Operationally, the Scottish perspective on ensuring cohesion between social security systems has focused on whether there would be a separate and independent Scottish social security agency, or a Scottish wing of the Department for Work and Pensions (DWP). In Northern Ireland, although social security has been a devolved matter since 1920, regional oversight has

\footnotetext{
* The author is a Reader in Law at Ulster University and a member of the Social Security Advisory Committee. The views expressed in this article should not be taken to represent the views of the Committee. The author is grateful to Dr Mark Simpson, Ulster University, for his comments and research assistance, and to Neville Harris, University of Manchester, Tom Mullen, University of Glasgow, Brian Thompson, University of Liverpool, and members of the Social Security Advisory Committee for their comments on a previous draft of this work.

${ }^{1}$ SSAC, Localisation and Social Security: a Review, Occasional Paper No.14 (2015); Work and Pensions Committee, The local welfare safety net: fifth report of session 2015-16 (2015) HC 373.
} 
This is a pre-copyedited, author-produced version of an article accepted for publication in the Journal of Social Security Law following editorial review. The definitive published version (Gráinne McKeever, "Legislative scrutiny, co-ordination and the Social Security Advisory Committee: from system coherence to Scottish devolution" (2016) 23(3) JSSL 126) is available online on Westlaw UK or from Thomson Reuters DocDel service.

traditionally been of secondary importance to the maintenance of parity of provision with Great Britain. Cohesion with (or duplication of) DWP policy and operations has largely been a given, albeit with some variation around the edges, and for which joined up approaches can be ensured.

The core features of social security remain broadly similar throughout each of the devolved regions in the UK, and the devolutionary powers operate to make discrete or partial change rather than fundamental reform. In one sense, therefore, the social security landscape across the $\mathrm{UK}$ is not drastically altered: the devolutionary developments have not been about radical departures from the uniform model - an ambition hampered by structural limitations set centrally at Westminster and fiscal realities that put some aspirations beyond reach - but about changing the outcomes, generally focusing more on mitigation than prevention. Yet it would be naïve to assume that the range of different reforms and processes across different parts of the UK will not have significant impact in their totality and in the individual cases to which they will apply. The co-ordination of social security, once a straightforward arrangement, is now impacted by increased policy divergence across the UK and the corresponding financial consequences, and that is before any of the constitutional uncertainty flowing from 'Brexit' begins to take hold (an issue beyond the reach of this article). ${ }^{2}$

With so much change, across so many different and moving parts, there is a need to understand the cumulative impact - not just on the local populations who are the focus of devolved governance, but on those populations that move within and between the devolved areas, bringing what are now complex geographical circumstances to an already complex system of assessing need. The interworking of devolutionary and central provision will undoubtedly create difficulties, not insurmountable and not destructive of devolution, but which will be of critical importance to the individuals who are affected. Inevitably there needs to be a means of anticipating and preventing unintended consequences that will present within the system as a whole, rather than simply within the local regimes that are being developed. In short, there is a need for oversight of the whole system so that the sum of the different parts provides the protection intended and not the collateral damage that an absence of joined-up working can create.

Perhaps understandably, the constitutional focus for devolution has been on exploring the extent to which social security powers can be relinquished or reserved, and the inevitable operational implications that flow from this; oversight has been overlooked. This article aims to expand that constitutional focus by exploring the need for a holistic oversight mechanism to deal with the challenges arising from devolutionary variations within the UK system. The question of whether there should be an oversight body to review the interaction of devolved and reserved social security provision is framed by the need for coherence: the individual parts of these interconnecting social security systems must work together for claimants throughout the UK to avoid adverse, unintended consequences.

The article begins with an exploration of how social security law is made, examining the deficit in the constitutional oversight of social security legislation by parliament through the increasing predominance of statutory instruments and departmental discretion, and

${ }^{2}$ J. Murkens, "Brexit: The Devolution Dimension", U.K. Constitutional Law Blog (28th June 2016) available at https://ukconstitutionallaw.org/ [accessed 28 June 2016]. 
This is a pre-copyedited, author-produced version of an article accepted for publication in the Journal of Social Security Law following editorial review. The definitive published version (Gráinne McKeever, "Legislative scrutiny, co-ordination and the Social Security Advisory Committee: from system coherence to Scottish devolution" (2016) 23(3) JSSL 126) is available online on Westlaw UK or from Thomson Reuters DocDel service.

the increased need, therefore, for effective scrutiny of draft regulations that aim to deliver the policy intent. An examination of the role of oversight then follows, focusing on the unique role of the Social Security Advisory Committee (SSAC), an independent body that provides advice to government on social security. This is followed by an analysis of the devolutionary arrangements for social security in the United Kingdom, to understand the political, constitutional and financial forces that have shaped the different settlements. Finally, the article concludes by considering the oversight options that might be developed to include oversight of devolved social security provision in Scotland, to deal with the problems of co-ordinating devolved social security provision, to enable coherence and connection within the systems of social security across the UK.

\section{Making social security law: the scrutiny gap}

The legislative apparatus that supports the social security system has the standard features of parliamentary debates and committee scrutiny of primary legislation, focusing on the powers that can be vested in the Secretary of State to give effect to social security policy choices, rather than on the detail of the means by which those powers will be delivered. The reality, however, is that only the bare bones of political power are set out in primary legislation leaving it to secondary legislation to detail what this means in practice. ${ }^{3}$ In relation to social security law, Ogus noted, in 1998, that "there has been an increasing tendency for legislation to be passed in skeletal form, leaving most of the rules to be prescribed in statutory instruments." ${ }^{4}$ Almost 20 years later, as the House of Lords Constitution Committee notes, this practice is now embedded:

"Successive governments have proposed primary legislation containing broad and poorly-defined delegated powers ... that give wide discretion to ministersoften with few indications as to how those powers should be used."5

This may be because the parliamentary process does not appear to be sufficient to provide full scrutiny of primary legislation: despite recent reform of the programming of Bills, debates in Committee stage often do not reach the end of the Bill, and so full scrutiny of the entirety of the piece, or specific provisions within it, is concluded prematurely. ${ }^{6}$ Meanwhile the advantage of secondary legislation, is the greater political flexibility it provides as governments seek to refine policy, but this comes at a constitutional cost:

"Delegated legislation cannot be amended, so there is little scope for compromise ... [T] here is little incentive for members of either House to ...

\footnotetext{
${ }^{3}$ It is worth noting, however, that the increasingly high level nature of social security primary legislation is far less true of state pensions than other social security benefits.

${ }^{4} \mathrm{~A}$ Ogus, "SSAC as an independent advisory body: its role and influence on policymaking" (1998) 5 J.S.S.L 156, p 168.

${ }^{5}$ Constitution Committee, Delegated Legislation and Parliament: A response to the Strathclyde Review, 9th Report of Session 2015-16 (2016) HL 116, p 2.

${ }^{6}$ See Select Committee on the Modernisation of the House of Commons, Programming of Bills: Session 2001-02 (2003) HC 1222. L. Thompson, "More of the same or a period of change? The impact of Bill committees in the 21st century House of Commons" (2013) 66 Parliamentary Affairs 459. In Northern Ireland and Scotland, the role of committees in legislative scrutiny must also be balanced with a range of other responsibilities - see Committee Review Group, Review of the committee system of the Northern Ireland Assembly (2013) NIA 135/11-15.
} 
This is a pre-copyedited, author-produced version of an article accepted for publication in the Journal of Social Security Law following editorial review. The definitive published version (Gráinne McKeever, "Legislative scrutiny, co-ordination and the Social Security Advisory Committee: from system coherence to Scottish devolution" (2016) 23(3) JSSL 126) is available online on Westlaw UK or from Thomson Reuters DocDel service.

[debate] legislation that they cannot change ... [and] established practice is that the House of Lords does not vote down delegated legislation except in exceptional circumstances. The result is that the Government can pass legislative proposals with greater ease and with less scrutiny where they are able to do so through secondary, rather than primary, legislation. These developments have strengthened the Executive at the expense of Parliament's legislative authority." 7

Social security legislation has followed this pattern, ${ }^{8}$ leading to concerns expressed by the Joint Committee on Human Rights (among others) ${ }^{9}$ that its ability to scrutinise the primary powers within the Welfare Reform Act 2012 was compromised by the vagueness of the primary legislation and the extent of political power that was being relegated to regulations that had not yet been published in draft form. ${ }^{10}$ Other scrutiny mechanisms are limited to technical aspects of the legislation, ${ }^{11}$ and where policy is considered this is limited (in the Lords) ${ }^{12}$ to non-binding advice or (in the Commons) ${ }^{13}$ to debate but not recommendations on approval or rejection. Devolved scrutiny processes are absent a second chamber - neither the Scottish Parliament nor the Northern Ireland Assembly has a revising chamber, so national scrutiny gaps are not plugged by devolved arrangements. ${ }^{14}$

There are two additional elements of law making that also require consideration. The first is the volume of statutory instruments being generated by the Executive, relative to primary legislation:

"[By December] 2015, the UK Parliament has passed 34 Acts, while, 1,999 statutory instruments have been made. (In fact, 2015 has been a relatively light year for statutory instruments: in 2013 and 2014, 3,292 and 3,486 statutory instruments were made.)"15

\footnotetext{
${ }^{7}$ Constitution Committee, Delegated Legislation and Parliament (2016) HL 116, p 2.

${ }^{8}$ Baroness Stowell in HL Debs, Vol.730, Col.696, 13 September 2011; see also Lord Boswell in HL Debs, Vol.730, Col.708, 13 September 2011.

${ }^{9}$ Similar concerns were expressed during parliamentary debates on the Act and in the Committee for Social Development report on Northern Ireland's Welfare Reform Bill: see, for example, J. McDonnell in HC Debs, Vol.524, Col.938, 9 March 2011; N. Long in HC Debs, Vol.524, Col.993, 9 March 2011; Committee for Social Development, Report on the Welfare Reform Bill (NIA Bill 13/11-15) (2013) NIA 74/11-15.

${ }^{10}$ Human Rights Joint Committee, Legislative Scrutiny: Welfare Reform Bill, Conclusions and Recommendations, Twenty-First Report of Session 2010-2012 (2011) HL 233/HC 1704, paras 1.161.17.

${ }^{11}$ Namely the Joint Committee on Statutory Instruments (UK Parliament), Delegated Powers and Law Reform Committee (Scottish Parliament) or Examiner of Statutory Rules (Northern Ireland Assembly): House of Commons Information Office, Statutory instruments: Factsheet L7, (2008); Examiner of Statutory Rules, Report of the Examiner of Statutory Rules to the Assembly and appropriate committees (2008) NIA333/11-16; Scottish Parliament, Guide to Scottish statutory instruments (year unknown).

12 Lords Committee on the Merits of Statutory Instruments.

${ }^{13}$ Commons Delegated Legislation Committee.

${ }^{14}$ Although see M. Cole, "Committee scrutiny in Scotland: a comparative and bi-constitutional perspective" (2016) 44 Policy and Politics 465, for an evaluation of the scrutiny undertaken through departmental committees at the Scottish Parliament which is seen as an improvement on the previous scrutiny of the Scotland Office, but with scrutiny gaps still remaining.

${ }^{15} \mathrm{M}$. Elliott, The House of Lords and secondary legislation: Some initial thoughts on the Strathclyde Review (17 December 2015), https://publiclawforeveryone.com/2015/12/17/the-house-of-
} 
This is a pre-copyedited, author-produced version of an article accepted for publication in the Journal of Social Security Law following editorial review. The definitive published version (Gráinne McKeever, "Legislative scrutiny, co-ordination and the Social Security Advisory Committee: from system coherence to Scottish devolution" (2016) 23(3) JSSL 126) is available online on Westlaw UK or from Thomson Reuters DocDel service.

Fox and Blackwell have attributed the proportionally high number of statutory instruments, in part, to the increase in social security legislation, highlighting the potential democratic deficit in the granting of social security powers to the Executive. 16

The second, additional element is where this pattern of law making is being stretched by the reliance on discretionary powers given as guidance to decision-makers to apply to individual social security claims. ${ }^{17} \mathrm{At}$ its best, this discretion provides a flexible means of filling the holes left by the legislation, enabling a responsive approach to individual circumstances. At worst, the reliance on discretion in place of statutory rules undermines the firm legal entitlement that legislation can provide, and results in variation in practice which challenges the certainty of the rule of law.18 Street-level decision makers cease to act as mere "functionaries of the state"; rather, bureaucracies formally charged with the implementation of policy become a further arena in which "political projects of change and welfare state transformation are advanced."19 The bureaucratic system of social security administration is designed to process huge numbers of claims with relative speed and efficiency, within strict parameters of entitlement bounded by bright line rules. ${ }^{20}$ The insertion of multiple opportunities to exercise discretion within this system runs counter to its economic and operational efficiency, and the discretionary provisions are often so opaque, nuanced or complex that it seems unreasonable to expect all decision makers to be au fait with their content, or consistent in their interpretation and application.

The increased reliance on discretion means that its role in the social security system has shifted from a supplementary element to a fundamental guarantor of human rights, with a reduction in the attendant rights of appeal.21 Discretionary Housing Payments (DHPs)

lords-and-secondary-legislation-some-initial-thoughts-on-the-strathclyde-review/ [accessed 4 August 2016].

${ }^{16}$ R. Fox and J. Blackwell, The Devil is in the Detail: Parliament and delegated legislation (London: Hansard Society, 2014), p 3, available at http://www.hansardsociety.org.uk/wpcontent/uploads/2014/12/The-Devil-is-in-the-Detail-exec.-summary.pdf [accessed 4 August 2016]. For discussion of the growth in complexity of social security law see N. Harris, Law in a Complex State (2015, Hart: Oxford). See also the foreword to the SSAC, Social Security Advisory Committee Annual Report 2015-16, 2016, noting that secondary legislation is regularly presented to the SSAC without meaningful analysis of impact.

${ }^{17}$ Fox and Blackwell, The Devil is in the Detail (London: Hansard Society, 2014). On a similar pattern in Australia see S. Argument Australian democracy and Executive law-making: Practice and principle (2016), available at http://www.aph.gov.au/About Parliament/Senate/Whats On/Seminars and Lectures/ /link.as px? id=A54FCE7B3A6340FDBF67B9AAEFFDAB8F\& $\mathrm{z}=\mathrm{z}$ [accessed 4 August 2016] and G. Appleby and J. Howe, "Scrutinising parliament's scrutiny of delegated legislative power" (2015) 15 Oxford University Commonwealth Law Journal 3.

${ }^{18}$ For discussion of the longstanding tension between discretion and certainty in social security law see J. Baldwin, N. Wikeley and R. Young, Judging social security: the adjudication of claims for benefit in Britain (Oxford: Clarendon Press, 1992).

${ }^{19}$ E.Z. Brodkin, 'Street level organisations and the welfare state' in E.Z. Brodkin and G. Marston (eds), Work and the welfare state: street level organisations and workfare policies (2013, Washington DC: Georgetown University Press).

${ }^{20}$ E. Laurie, (2009) "Judicial responses to bright line rules in social security: in search of principle" (2009) 72 Modern Law Review 384.

21 The increasing use of front line discretion has not been an overnight development but rather reflects a major shift over several decades in successive governments' views of the social security 
This is a pre-copyedited, author-produced version of an article accepted for publication in the Journal of Social Security Law following editorial review. The definitive published version (Gráinne McKeever, "Legislative scrutiny, co-ordination and the Social Security Advisory Committee: from system coherence to Scottish devolution" (2016) 23(3) JSSL 126) is available online on Westlaw UK or from Thomson Reuters DocDel service.

provide the most robust demonstration of this point, given the government's argument in $R$ (on the application of MA $v$ Secretary of State for Work and Pensions) that the discrimination embedded in the Social Sector Size Criteria (colloquially known as the 'bedroom tax') becomes proportionate and justifiable through the discretionary mitigation provided by DHPs.22 In addition, discretionary provision, administered locally, further evidences the trend towards localisation - particularly in relation to what was originally the social fund, and the independent living fund, as well as council tax benefit, and UC and universal support delivered locally - where fewer oversight mechanisms exist. ${ }^{23}$

The pattern of reducing parliamentary scrutiny is continuing with the governmentcommissioned Strathclyde Review which recommended removing the power of the House of Lords to veto statutory instruments by granting powers to the House of Commons to override the Lords' opposition to secondary legislation. ${ }^{24}$ The responses of the House of Lords Constitution Committee and the Delegated Powers and Regulatory Reform Committee are highly critical of the proposal, with the former stating that such reform "risks turning an already deeply flawed process into a farce." 25 The responses identify an incentive to take controversial powers out of primary legislation and use inferior secondary legislation scrutiny provision to extend executive powers. At the heart of the objections is that the Review incorrectly focuses on the balance of power between the Commons and the Lords, when what is at stake is the balance of power between the executive and parliament:

system for those of working age as being less about an entitlements payments system and more about influencing behaviour and enforcing links with the labour market.

${ }^{22} R$ (on the application of MA and others) $v$ Secretary of State for Work and Pensions [2014] EWCA Civ 13 [2014] PTSR 584; J. Meers, "Panacean Payments: The Role of Discretionary Housing Payments in the Welfare Reform Agenda" (2015) 22 J.S.S.L. 115. That the legal challenge mounted against this provision has had to be via judicial review is mandated by the exclusion of DHPs from the jurisdiction of the First-tier Tribunal, limiting the accessibility of legal challenge and accountability. See also the report of the SSAC raising concerns that claimant awareness of DHPs was not universal: Report on the Housing Benefit and Universal Credit (Size Criteria) (Misc Amendments) Regulations 2013 (2013). See further the SSAC, Minutes: March 2016, section 2.4 (h) which identify the increasing practice of relying on detailed and specific guidance for decision makers in order to advise claimants of the correct legal position and the implications of their behaviour vis a vis their benefit entitlement.

${ }^{23}$ SSAC, Localisation and Social Security (2015), pp 11-18.

${ }^{24}$ See M. Elliott, Parliament, government and secondary legislation: Lords Select Committees respond to the Strathclyde Review, 23 March 2016, https://publiclawforeveryone.com/2016/03/23/parliament-government-and-secondary-

legislation-lords-select-committees-respond-to-the-strathclyde-review/ [accessed 4 August 2016]. The review was commissioned in the wake of the House of Lords vote to delay secondary legislation relating to tax credits cuts: Strathclyde Review: Secondary legislation and the primacy of the House of Commons (2015) Cm 9177, https://www.gov.uk/government/uploads/system/uploads/attachment data/file/486790/530

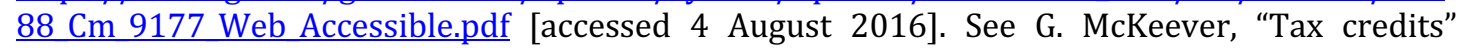
(2016) 23 J.S.S.L. $12-13$

25 Constitution Committee, Delegated Legislation and Parliament (2016) HL 116, p 18; the original source for this quotation is R Fox and J Blackwell, Reflections on the Strathclyde Review (13 January 2016) https://constitution-unit.com/2016/01/13/reflections-on-the-strathclydereview/ [accessed 4 August 2016]. See also the Delegated Powers and Regulatory Reform Committee, Special Report: Response to the Strathclyde review, 25 th report of session 2015-16 (2016) HL 119. 
This is a pre-copyedited, author-produced version of an article accepted for publication in the Journal of Social Security Law following editorial review. The definitive published version (Gráinne McKeever, "Legislative scrutiny, co-ordination and the Social Security Advisory Committee: from system coherence to Scottish devolution" (2016) 23(3) JSSL 126) is available online on Westlaw UK or from Thomson Reuters DocDel service.

"The focus should be on how to ensure that the actions of the Executive are scrutinised effectively and that parliamentary approval of delegated legislation-by members of both Houses of Parliament-is not a mere boxticking exercise." 26

Once again, the implications for social security are profound. The nature of social security provision is further removed today than ever before from the ideological conception on which state social security was built, moving away from a state controlled, insurance based system of rights, built on contributions that spread, collectively, the poverty risks associated with unemployment, sickness, old age and death, to a model where the responsibility for controlling risk shifts to the individual, who is managed through a growing set of conditions and attendant sanctions, ${ }^{27}$ with state responsibilities diluted and dispersed to different layers of decision makers and local budgets. ${ }^{28}$ Nonetheless, the most elemental feature of the law making process is that the executive's ideological ambitions cannot take priority over parliamentary sovereignty and so the role of statutory oversight by parliament remains critical. The independent judicial review provided by litigation can help to remedy some of the deficiency in scrutiny, but this is necessarily an individual cure rather than systematic prevention. Given the oversight deficit in the legislative apparatus, anything that provides an additional layer of scrutiny of social security regulations can be welcomed as supporting parliamentary sovereignty and ensuring legitimacy.

\section{The role of oversight bodies: plugging the scrutiny gap?}

Oversight bodies can provide scrutiny of government actions, increasing government's accountability and transparency while providing advice as to how government functions and policy objectives might be improved or discharged. These arms-length bodies (ALBs) perform a consultative or expert role, and are intended to bring independence and expertise into the delivery of policy, to help regulate services, and to provide advice. ${ }^{29}$ Their main advantage is seen to be their ability to de-politicise decision making and build public trust, as well as providing access to specialist advice and expertise that would be more costly to deliver through consultancy-based services..$^{30}$ The advantages, however, have been often regarded as insufficient to off-set the public, political and media perspectives of ALBs as unaccountable, wasteful, and self-serving, leading successive political leaders to make manifesto promises about their abolition. The most

${ }^{26}$ Constitution Select Committee, Delegated Legislation and Parliament (2016) HL 116, p 19.

${ }^{27}$ N. Harris, "From unemployment to active jobseeking: changes and continuities in social security law in the United Kingdom", S. Stendahl, T. Erhag and S. Devetzi (eds), A European workfirst welfare state (2008, Gothenburg: Centre for European Research); M. Adler, "A new leviathan: benefit sanctions in the 21 ${ }^{\text {st }}$ century: (2016) 43 Journal of Law and Society 195.

${ }^{28}$ See, for example, DHPs - and the role of discretion more broadly - as part of the government's ideological drive towards austerity: J. Meers, "Panacean Payments" (2015) 22 J.S.S.L. 115, p 120.

${ }^{29}$ Also known as quasi-autonomous non-governmental organisations (Quangos) and nondepartmental public bodies (NDPBs). See Public Administration Select Committee, Who's accountable? Relationships between government and arms-length bodies: first report of session 2014-15 (2014) HC 110.

${ }^{30}$ T. Gash, I. Magee, J. Rutter and N. Smith, Read Before Burning: Arm's length government for a new administration, (Institute for Governance, 2010), http://www.instituteforgovernment.org.uk/sites/default/files/publications/Read\%20before $\% 2$ oburning.pdf [accessed 4 August 2016]. 
This is a pre-copyedited, author-produced version of an article accepted for publication in the Journal of Social Security Law following editorial review. The definitive published version (Gráinne McKeever, "Legislative scrutiny, co-ordination and the Social Security Advisory Committee: from system coherence to Scottish devolution" (2016) 23(3) JSSL 126) is available online on Westlaw UK or from Thomson Reuters DocDel service.

recent assault was conducted by the UK coalition government in 2010: 904 organisations were reviewed across 16 departments within five months. The review established a two-fold test for whether a body was to be retained. First, does the body need to exist or is its role/function now superfluous? Second, if its function is necessary, does the function need to be undertaken outside a department? The second question was to be answered in reference to three specific criteria: does it perform a technical function? Does it need to be politically impartial? Does it act independently to establish facts? The resulting 'bonfire of the quangos' was the abolition of more than 150 bodies which failed to meet the test, and the merger of 160 bodies into fewer than $70 .^{31}$

The Social Security Advisory Committee (SSAC) was one of the ALBs that survived untouched. ${ }^{32}$ Sponsored by the DWP, the SSAC provides advice to the Secretary of State and the relevant Northern Ireland department on social security and related matters. ${ }^{33}$ When the Committee was set up in 1980,34 the Secretary of State noted that:

"For the first time Ministers and the House will have the benefit of advice from an independent advisory body which spans the major part of our social security system." 35

The SSAC's advice function covers three areas:

"First, the Secretary of State may seek its advice on any matter within its remit. Secondly, the Committee may give advice on any such matter, whether or not it has been specifically asked to do so. The third function is believed to be unique for an advisory body dealing with such a highly significant area of policymaking. The Secretary of State is under a duty to submit to it for comments all proposals for making regulations, in the form of subordinate legislation, under the relevant parliamentary enactments." 36

In practice, the SSAC's advice is given predominantly through the mandatory scrutiny of proposals in the form of draft regulations, helping to plug the legislative scrutiny gap that arises from parliamentary processes. ${ }^{37}$ Some areas of social security are exempt

\footnotetext{
${ }^{31}$ Cabinet Office, Public bodies 2015: save, deliver, transform (2015); see also Shrinking the State project outputs at http://shrinkingthestate.group.shef.ac.uk.

${ }^{32}$ Another ALB, the Industrial Injuries Advisory Council, has a very specific social security remit, to provide expert scientific advice on the Industrial Injuries Scheme, and has continued to survive DWP reviews: see DWP, Triennial Review of the Industrial Injuries Advisory Council (2015) available at https://www.gov.uk/government/publications/industrial-injuries-advisory-counciltriennial-review-2015 [accessed 4 August 2016]. A third ALB, the Administrative Justice and Tribunals Council, that had oversight of DWP decision making, was abolished in 2013: see C. Skelcher, "Reforming the oversight of administrative justice 2010-2014: does the UK need a new Leggatt Report?” (2015) Public Law 215-224; G. McKeever, "Improving decision making in Employment and Support Allowance" (2014) 21 J.S.S.L. 13.

33 Social Security Administration Act 1992, s170 and the Social Security Administration (Northern Ireland) Act 1992, ss149-151 and Sch 5.

${ }^{34}$ Social Security Act 1980 ss 9-10. See N. Wikelely, and A. Ogus, The Law of Social Security (Butterworths: London, 2002) pp137-138.

35 HL Debs. Vol.407, Col.1268, 1 April 1980.

${ }^{36}$ Ogus, "SSAC as an independent advisory body" (1998) 5 J.S.S.L. 156, p 156.

37 See J Logie, "The Social Security Advisory Committee" (1989) 23 Social Policy and
} Administration 248 for discussion on the Committee's functions 
This is a pre-copyedited, author-produced version of an article accepted for publication in the Journal of Social Security Law following editorial review. The definitive published version (Gráinne McKeever, "Legislative scrutiny, co-ordination and the Social Security Advisory Committee: from system coherence to Scottish devolution" (2016) 23(3) JSSL 126) is available online on Westlaw UK or from Thomson Reuters DocDel service.

from scrutiny, 38 as are any regulations promulgated within six months of the primary legislation. ${ }^{39}$ In addition, urgency provisions may be invoked where the government considers that it is necessary to lay the regulations before the SSAC has had time to scrutinise them, but the regulations must then be referred to the SSAC after they have been laid.40

Of particular relevance to this article is the constitution of the Committee, which reflects the statutory requirement for one of the 13 members to be appointed by the Secretary of State after consultation with the head of the Northern Ireland department. ${ }^{41}$ Custom and practice has been to ensure that there are members appointed to represent Scotland and Wales, to assist the Committee's scrutiny of the potential issues arising for regional populations. The Scottish and Welsh appointments are not made in formal consultation with the respective Secretaries of State, but informal discussions with senior officials in Scotland and Wales take place at various stages throughout the recruitment process, with officials part of the interview panels, and Secretaries of State are notified of the appointments. ${ }^{42}$ The result has been that the Committee has been constituted purposely to enable it to look at the structure of social security benefits across the UK and to consider the regional implications that arise, although a single appointment for each of the devolved jurisdictions is perhaps nominal rather than substantive representation.

Following the outcome of the 2010 public bodies review, the Cabinet Office confirmed that the SSAC's function remained necessary and that it met all three criteria used to determine whether the function should be undertaken outside the department. ${ }^{43}$ The DWP's 2012 review of the SSAC found that the decision to retain rested in particular on the grounds of performing functions requiring political impartiality. ${ }^{44}$ The review team concluded that the Committee plays a useful role in scrutinising regulations and providing advice on the implications, interactions and possible unintended

\footnotetext{
${ }^{38}$ Namely industrial injuries, child support, and war pensions or occupational pensions.

39 The Committee can, however, be invited to comment informally on regulations made within six months of the primary legislation.

40 The six months rule was an established pattern that was formalised through the Social Security Act 1986 s 61, and the urgency provisions gave effect to a situation that had originally been considered as part of the Social Security Bill in 1980 but was not regarded at the time as likely to arise. The most recent use of the urgency provisions by the Secretary of State was in relation to Jobseeker's Allowance (Habitual Residence) Amendment Regulations 2013, SI 3196, and for the Northern Ireland Department of Social Development in relation to Housing Benefit (Executive Determinations) (Amendment) Regulations (Northern Ireland) 2015 SR 2. The former Regulations were challenged unsuccessfully before the Upper Tribunal in Scotland as being ultra vires, the failed argument being that the urgency required was of the Secretary of State's own making: CSH/110/2015.

${ }^{41}$ Social Security Administration Act 1992, Sch 5, para 3(1)(c). The Schedule also provides for the appointment of two members after consultation with organisations representative of employers (para 3 (1)(a)) and organisations representative of workers (para 3 (1)(b)) as well as the inclusion of at least one person with experience of the needs of the chronically sick and disabled.

42 The Committee has also appointed regional advisers in the past, to strengthen its awareness of regional issues.

${ }^{43}$ Cabinet Office and Efficiency and Reform Group, Public bodies reform: proposals for change (2011).

${ }_{44}$ DWP, A Review by the Department for Work and Pensions of the Social Security Advisory Committee (2012).
} 
This is a pre-copyedited, author-produced version of an article accepted for publication in the Journal of Social Security Law following editorial review. The definitive published version (Gráinne McKeever, "Legislative scrutiny, co-ordination and the Social Security Advisory Committee: from system coherence to Scottish devolution" (2016) 23(3) JSSL 126) is available online on Westlaw UK or from Thomson Reuters DocDel service.

consequences of Government proposal.45 In addition, it found that the SSAC's specialised technical knowledge of social security matters was its greatest strength and that political impartiality and independence from Ministers was crucial and would be particularly important at a time of major reform to the welfare system. ${ }^{46}$ Three years later, the 2015 review of the SSAC concluded that:

"The ... reasons [cited in the 2012 review] for additional scrutiny of social security secondary legislation still stand. Nothing has happened in the time since June 2012 to weaken these arguments. Some of the responses to the external consultation would suggest that this additional scrutiny has ... never been more important." 47

The context in which the SSAC was created in 1980 is vastly different from the context of social security delivery today, both in terms of the core principles underpinning social security that place reduced emphasis on contributory benefits and more focus on conditionality and discretionary decision-making, and in terms of the devolutionary developments that see the system moving away from the centre towards local control. Yet the Committee has demonstrated its durability through all of this, managing not just to avoid the constitutional concerns that have condemned other ALBs, but to use its oversight function to contribute to the checks and balances of constitutional scrutiny, adding value in particular to the work of the Work and Pensions Committee, the Secondary Legislation Scrutiny Committee, and that of individual MPs and Peers.48 Scrutinising the changing nature of social security provision is a challenge that the Committee has proved able to manage. What has not been tested fully, however, is how the role of the Committee can develop with the changing devolutionary landscape.

\section{Devolutionary social security in the UK}

The devolutionary arrangements across the UK have been ad hoc and asymmetric, politically driven rather than developed in accordance with agreed constitutional principles. ${ }^{49}$ There are no obvious international comparators to guide how social security devolution might work, given that the UK does not fit easily into the traditional devolutionary models of cooperative or competitive federalism. Co-operative federalism exists where power is decentralised but there is a common policy framework across central and devolved administrations, providing a baseline statement of rights with defined boundaries beyond which the devolved administrations cannot go. In Keating's analysis, this involves the "the federal level legislating on broad principles and the lower

\footnotetext{
45 DWP, A Review by the Department for Work and Pensions of the Social Security Advisory Committee (2012) p 5.

${ }^{46}$ DWP, A Review by the Department for Work and Pensions of the Social Security Advisory Committee (2012) p 5.

${ }^{47}$ S. Stoney, 'Triennial review report: Social Security Advisory Committee' (2015, DWP) p 13.

${ }^{48}$ See evidence to the 2012 Review of the value of SSAC to the parliamentary scrutiny process: DWP, A Review by the Department for Work and Pensions of the Social Security Advisory Committee (2012) p 12. See also HL Debs, Vol.730, Col.684, 13 September 2011 (on the Welfare Reform Bill); Public Bill Committee, 17 September 2015, $6^{\text {th }}$ sitting, col.255 (on the Welfare Reform and Work Bill); HC Debs, Vol.604, Col.295, 6 January 2016 (on Universal Credit Work Allowance).

${ }^{49}$ Constitution Select Committee, The Union and devolution: $10^{\text {th }}$ report of session 2015-16 (2016) HL 149.
} 
This is a pre-copyedited, author-produced version of an article accepted for publication in the Journal of Social Security Law following editorial review. The definitive published version (Gráinne McKeever, "Legislative scrutiny, co-ordination and the Social Security Advisory Committee: from system coherence to Scottish devolution" (2016) 23(3) JSSL 126) is available online on Westlaw UK or from Thomson Reuters DocDel service.

level filling in the details".50 Competitive federalism, however, sees governments competing for economic advantage, "to attract desirable residents", with the potential outcome for social rights being either a race to the bottom or - as Keating has characterised the pattern in the UK and Europe - a race to the top. ${ }^{51}$ Section 87 of the Northern Ireland Act 1998, which requires cooperation on the coordination of social security systems between Northern Ireland and Britain, might well be an example of cooperative federalism. At the same time, the relationship between the Scottish and UK governments might be more typical of competitive federalism, given the Scottish National Party (SNP) rhetoric on providing something different - 'better' - than exists under the social security system in Britain. ${ }^{52}$

Nor is there a clear guide to navigating the inherent conflict with devolutionary arrangements, between ensuring coherence between national and devolved provision and enabling devolutionary diversity. Some devolutionary states have sought to strike a balance between coherence and diversity in core welfare services by establishing minimum standards through national framework legislation while allowing for significant regional divergence in how these minimum standards might be supplemented, ${ }^{53}$ or by constitutionally designating particular fields of policy as shared competences. ${ }^{54}$ However, this approach has not been a significant feature of the UK landscape, in which a stricter division of competences had been maintained, ${ }^{55}$ but with changes in devolved powers and governments the division of competence has been blurred, creating greater potential for intergovernmental conflict. The shifts between coherence and divergence will always be finely balanced, but the need to protect social security claimants moving between systems from adverse, unintended consequences remains paramount.

\section{Northern Ireland}

Social security has been a devolved issue in Northern Ireland since the Government of Ireland Act 1920, under which the powers to create a Northern Ireland specific social security system were handed to a unionist-controlled Parliament of Northern Ireland and have remained within Northern Ireland's control save for intervening periods of direct rule from Westminster. ${ }^{6}$ The unionist government's manifesto was to maintain

\footnotetext{
50 M. Keating, The government of Scotland: public policy making after devolution (Edinburgh: Edinburgh University Press, 2010) p138.

${ }^{51} \mathrm{M}$. Keating, "Intergovernmental relations and innovation: from co-operative to competitive welfare federalism in the UK" (2012) British Journal of Politics and International Relations 214, p 217.

52 See Scottish Government, Creating a Fairer Scotland: A New Future for Social Security in Scotland (2016), available at: http://www.gov.scot/Topics/People/fairerscotland/futurepowers/Publications/Future [accessed 4 August 2016].

53 A. Losada and R. Máiz, "Devolution and involution: defederalisation politics through educational policies in Spain (1996-2004)" (2005) 15 Regional and Federal Studies 437; G. Rodríguez Cabrero, "La protección social de la dependencia en España: un modelo sui generis de desarrollo de los derechos sociales" (2007) 44 Política y Sociedad 69.

${ }^{54} \mathrm{~A}$. Benz, "Intergovernmental relations in German federalism: joint decision-making and the dynamics of horizontal cooperation" (Hagen: Fernuniversität in Hagen, 2009).

55 M. Keating, "What's wrong with asymmetrical government?" (1998) 8 Regional and Federal Studies 195; A. Trench, "Legislative comment: the Government of Wales Act 2006: the next steps on devolution for Wales" (2006) Public Law 687.

56 Devolution was suspended for most of the period from 1972 to 2007. See G. Walker, "Scotland, Northern Ireland and Devolution: Past and Present" (2010) 24 Contemporary British History 235;
} 
This is a pre-copyedited, author-produced version of an article accepted for publication in the Journal of Social Security Law following editorial review. The definitive published version (Gráinne McKeever, "Legislative scrutiny, co-ordination and the Social Security Advisory Committee: from system coherence to Scottish devolution" (2016) 23(3) JSSL 126) is available online on Westlaw UK or from Thomson Reuters DocDel service.

Northern Ireland as part of the UK, governed in the same way and under the same laws as the rest of the UK. This political imperative of parity ignored the differing manifestations and extent of poverty in Northern Ireland, and the fiscal impossibilities that a matched system of social security provision created: higher levels of unemployment in the region created the simultaneous consequence of greater demand on the national insurance system at a time when there were fewer people paying national insurance contributions. Subsidies from the UK Exchequer that were offered on a temporary basis in 1926 have been effectively maintained since then, further embedding the convention of parity. ${ }^{57}$ The resulting symmetry between the social security systems in Britain and Northern Ireland is recognised in the Northern Ireland Act 1998, which does not prescribe parity but underlines the rationale for its continued practice. ${ }^{58}$ Section 87 of the Act requires consultation on the co-ordination of policy between the relevant Ministers in Britain and Northern Ireland but the reality is that agreement on social security developments is premised on a financial imperative that reduces the scope for ideological or operational divergence.

A co-ordinated process, however, has the advantage of shared oversight, allowing the Northern Ireland department to move into DWP's slipstream, to mirror the DWP regulations that have already been subject to scrutiny. ${ }^{59}$ Difficulties in the mirror-image model can arise from either the differential impacts on Northern Ireland, ${ }^{60}$ or where cross-departmental impacts arise, particularly where Northern Ireland departments have not reflected the profile of their British counterparts. ${ }^{61}$ From an oversight perspective, there is a need to be attentive to these variations, and to work within the limitations of a parity model, focusing on parity of outcome through the avoidance of unintended, geographically specific consequences.

Birrell and Heenan have argued that the SSAC has paid relatively little attention to Northern Ireland, in part because "UK-wide bodies do not pay a great deal of attention to Northern Ireland matters ...".62 It is true that one member cannot adequately provide

M. Simpson, "Developing constitutional principles through firefighting: social security parity in Northern Ireland" (2015) 22 J.S.S.L. 31.

${ }^{57}$ Simpson, "Developing constitutional principles through firefighting" (2015) 22 J.S.S.L 31, pp 36-37.

${ }^{58}$ Section 87. See G. McKeever, "Reforming social security appeal tribunals in Northern Ireland: parity whether we Leggatt or not?" (2010) 17 J.S.S.L. 71, pp 77-78.

${ }^{59}$ Northern Ireland Assembly, Understanding parity - departmental briefing paper (2011) Research Paper 99/11, para. 8 http://www.niassembly.gov.uk/globalassets/documents/socialdev/urban-regen/dsd briefing_paper_parity.pdf [accessed 4 August 2016].

${ }^{60}$ For example, in relation to cross-border working arrangements or housing policy limited by a 'sectarian' geography and available social stock - see Committee for Social Development, Report on the Welfare Reform Bill (NIA Bill 13/11-15) (2013) NIA 74/11-15, Minutes of evidence - 25 October 2012; K Gibb, The 'bedroom tax' in Scotland (2013) Scottish Parliament paper 409; SSAC, Minutes: 27 January 2016.

61 For example, in relation to work-focused conditionality, controlled in Britain by DWP but controlled in Northern Ireland (up to May 2016) by a separate Department of Employment and Learning. See Northern Ireland Assembly, Understanding parity (2011) Research Paper 99/11, para. $\quad 8 \quad$ http://www.niassembly.gov.uk/globalassets/documents/social-dev/urbanregen/dsd briefing paper parity.pdf [accessed 4 August 2016]. Responsibility for employment services and social security in Northern Ireland has now been united within the new Department for Communities.

${ }^{62}$ D. Birrell and D. Heenan, "Devolution and social security: the anomaly of Northern Ireland" (2010) 18 Journal of Poverty and Social Justice 281, p. 289. 
This is a pre-copyedited, author-produced version of an article accepted for publication in the Journal of Social Security Law following editorial review. The definitive published version (Gráinne McKeever, "Legislative scrutiny, co-ordination and the Social Security Advisory Committee: from system coherence to Scottish devolution" (2016) 23(3) JSSL 126) is available online on Westlaw UK or from Thomson Reuters DocDel service.

the definitive voice of a jurisdiction - whether for Northern Ireland, Scotland or Wales and that the national sub-state positions could be represented better, for example through home-grown advisory groups that feed into a coordinated consultation input. But while there is always the difficulty that the single perspective gets lost within the wider discussion, there is also evidence of the SSAC taking a specific interest in the relevant issues for Northern Ireland. In 2011, for example, the Committee produced a detailed response to the Northern Ireland Department for Social Development's consultation on the proposals that led (in Britain) to the Welfare Reform Act 2012, identifying the proposals that could be problematic for Northern Ireland, while recognising the continuing pattern of social security convergence. 63 The Committee's minutes also demonstrate that there are regular updates provided on developments in Northern Ireland and considerations of Northern Ireland-specific issues arising from regulations. ${ }^{64}$ The SSAC consultations take account of evidence from stakeholders in Northern Ireland and the Committee visits Northern Ireland as part of its stakeholder engagement and to understand the out-workings of parity-based legislation. ${ }^{65}$

The parity paradox has been a vexing political issue for Northern Ireland. The powers to create a bespoke social security system have already been granted to the Northern Ireland executive, but the ability to exercise those powers remain thwarted, even though the political imperative for parity is less dominant within a power-sharing executive that has a mix of nationalist and unionist outlooks. What has supplanted this imperative is the need for financial agreement: the 1926 position of political parity driving the need for financial subsidies has instead become one where parity is consequential to financial subsidy and not the driver of it. Attempts to break free from this model - and from the ideological position underpinning the Welfare Reform Act 2012 - have led to a series of constitutional cliff-edges on which the Northern Ireland Assembly has been perched. The latest intergovernmental agreement - the 2015 "Fresh Start" agreement - has been enough to save the Assembly from falling, but does not escape the parity bind that led to the cliff in the first place.66 The "Fresh Start" agreement allows the Northern Ireland

63 SSAC, 21st Century Welfare: SSAC response to DSD in Northern Ireland https://www.gov.uk/government/publications/21st-century-welfare-ssac-response-to-dsd-innorthern-ireland [accessed 4 August 2016].

${ }^{64}$ See for example SSAC, Minutes: 27 January 2016, where the Northern Ireland dimension was part of the Committee's decision to take DWP regulations on formal referral: https://www.gov.uk/government/uploads/system/uploads/attachment_data/file/500459/ssac -minutes-270116.pdf.

65 The February 2016 stakeholder visit to Northern Ireland involved the Committee meeting with the Social Development Minister, senior officials in the Department for Social Development and the Social Security Agency, Social Security Agency frontline staff, the Social Security Commissioners for Northern Ireland, the Social Development Committee, and with a range of voluntary sector groups.

${ }^{66}$ Northern Ireland Office, A fresh start: the Stormont agreement and implementation plan (2015). For discussion, see M. Simpson, "The social union after the coalition: devolution, divergence and convergence" (2016) Journal of Social Policy 1. The constitutional solution that arose from this political agreement was to pass Northern Ireland's devolved social security powers back to Westminster through a Legislative Consent Motion, which gave authority to Westminster to pass the (expedited) Northern Ireland (Welfare Reform) Act 2015, which in turn gave the UK government the authority to pass the Welfare Reform (Northern Ireland) Order 2015, which replicates the Welfare Reform Act 2012 (with some limited exceptions) and gives the Secretary of State for Northern Ireland the power to make the associated regulations. The Legislative Consent Motion also gives authority to Westminster to approve the welfare clauses of the Welfare Reform and Work Bill as initially introduced at Westminster, with any amendments to be 
This is a pre-copyedited, author-produced version of an article accepted for publication in the Journal of Social Security Law following editorial review. The definitive published version (Gráinne McKeever, "Legislative scrutiny, co-ordination and the Social Security Advisory Committee: from system coherence to Scottish devolution" (2016) 23(3) JSSL 126) is available online on Westlaw UK or from Thomson Reuters DocDel service.

Assembly to deviate from the welfare reforms by providing temporary, transitional protection, 67 alongside some softening of the hardest edges of reform. ${ }^{68}$ Policy divergence focuses on mitigating the impact of the 'bedroom tax', providing additional support for carers and the disabled, replacing the Social Fund, not implementing the highest level of sanction, operational variations in UC and a new policy initiative to create a 'cost of working allowance' to mitigate the forthcoming cut in working allowance for UC. The pattern of parity will continue to drive devolution for the near future but the events of 2011 to 2015 show that regional legislators are now less willing to accept that parity can "simply be justified by default." 69 The challenge will be to understand the mix of devolved provision alongside centrally determined entitlements. The importance of oversight for Northern Ireland is therefore likely to increase. The question that arises is whether there is a need for a similar role in relation to devolved social security arrangements in Scotland.

\section{Scotland}

The granting of devolved social security powers in Scotland is considerably more recent than in Northern Ireland, and while similar fiscal restraints underpin the social security settlements, the move to devolution in Scotland has been influenced by different factors. Where the history of social security devolution in Northern Ireland is grounded in a politically driven desire for parity, Scottish history speaks more clearly to a consensus on Scottish national identity, distinct from the rest of the UK, emerging from the postworld war two arguments for Scottish home rule. The realisation of such ideological divergence faced similar financial limitations that were evident in Northern Ireland, namely a much higher unemployment rate than in England and the need for a substantial financial settlement to deal with this. The difference for the Westminster government, however, concerned Scotland's relative political power. Walker notes that not only did the Westminster government wish to avoid replicating (with Scotland) what it saw as an unsatisfactory financial relationship with Northern Ireland, but that it regarded Scotland as being in a more stable and unified political state than Northern Ireland that would put Scotland in a stronger position to demand a more attractive devolutionary settlement. ${ }^{70}$ While the post-1945 welfare state and its benefits of

brought back to the Northern Ireland Assembly: See G. McKeever, "Welfare reform in Northern Ireland" (2016) 23 J.S.S.L. 8-10.

67 Welfare Reform Mitigations Working Group, Report (2016) available at https://www.executiveoffice-ni.gov.uk/sites/default/files/publications/ofmdfm/welfarereform-mitigations-working-group-report.pdf [accessed 5 June 2016]; see McKeever, "Welfare reform in Northern Ireland" (2016) 23 J.S.S.L. 9-10.

${ }^{68}$ Most notably through the political agreement that the Social Sector Size Criteria, or 'bedroom tax', will not be applied to Northern Ireland for four years, although the legislative vehicle for this has not yet been agreed; that the highest level sanction will not apply to Northern Ireland; and some claimants will be compensated for financial loss, normally for a year.

${ }^{69}$ McKeever, "Reforming social security appeal tribunals in Northern Ireland?" (2010) 17 J.S.S.L. 71,77 . Further, as the recent judicial review of the eligibility criteria for widowed parent's allowance demonstrates, the more onerous requirements for human rights compliance placed on the devolved legislatures have potential to underpin a legal challenge to parity: In the matter of an application by Siobhan McLaughlin for judicial review [2016] NIQB 11; see also M. Simpson, "Case analysis" (2016) 23 J.S.S.L. 106.

70 Walker "Scotland, Northern Ireland and Devolution" (2010) 24 Contemporary British History 235, pp 238-9. Walker points to the evidence of this in the decision of the Scottish Council of the Labour Party in 1958 to drop its historic commitment to Scottish Home Rule. 
This is a pre-copyedited, author-produced version of an article accepted for publication in the Journal of Social Security Law following editorial review. The definitive published version (Gráinne McKeever, "Legislative scrutiny, co-ordination and the Social Security Advisory Committee: from system coherence to Scottish devolution" (2016) 23(3) JSSL 126) is available online on Westlaw UK or from Thomson Reuters DocDel service.

universalism served to undo many of the arguments for a Scottish government,71 it was the long period of Conservative rule from 1979-1997 that enabled the narrative of Scottish devolution to refocus on the distinctiveness of Scottish identity, in ideological opposition to Conservative policies, including social security. ${ }^{72}$ In essence, the social union that had acted as the glue for Scotland to remain within the UK began to come unstuck.

The Scotland Act 1998, which created the powers to establish a devolved national legislature, did not devolve any social security powers to the Scottish Parliament,73 leading Spicker to conclude that "the formal powers of the Scottish government in respect of benefits [were] less than those of an English local authority." 74 Such restrictions went against the grain of political developments in Scotland, where the devolved government, led from 2007 by the SNP, was developing a more distinctive anti-poverty rhetoric in its push for Scottish independence. ${ }^{75}$ Some limited powers to promote welfare were provided under the Local Government (Scotland) Act 2003 and these were used by the Scottish government in the 2011-2016 administration to initiate different schemes in response to welfare reforms brought forward by the UK government. ${ }^{6}$ Scott and Wright, however, point to the lack of debate by the SNP government on UK-wide cooperation on core questions of poverty, highlighting the double bind of fiscal constraints on policy divergence alongside the apparent incompatibility of social security ideology north and south of the Scottish border.77

Up to this point, therefore, the role of the SSAC in relation to Scotland was to consider the specific impact of DWP proposals on Scotland. As with Northern Ireland, the danger remains of losing sight of a national, sub-state focus within the wider UK agenda, but similarly there is evidence of the SSAC managing this balance to enable specific consideration of Scottish issues to give effect to its customary obligation to Scotland, through which deeper consideration can be given to the wider policy issues. The Committee's minutes, independent reports, consultations, confidential discussions with

71 Walker "Scotland, Northern Ireland and Devolution" (2010) 24 Contemporary British History 235, p 246; G. Lodge and A. Trench, "Devo more and welfare: devolving benefits and policy for a stronger union" (2014, London: IPPR) p 6.

72 See L. Patterson, A Diverse Assembly: The debate on a Scottish Parliament (Edinburgh: Edinburgh University Press, 1998); G. Leicester, Scotland's parliament: fundamentals for a new Scotland Act (London: Constitution Unit, 1996); G. Mooney and C. Williams, "Forging new 'ways of life'? Social policy and nation building in devolved Scotland and Wales" (2006) 26 Critical Social Policy 458; K Morgan, "Devolution and development: territorial justice and the north-south divide" (2006) 36 Publius 189.

73 The Scotland Act 1998, ch 46, Schedule 5F. The powers given to the Welsh assembly likewise excluded social security powers: Government of Wales Act 1998 c38; Government of Wales Act 2006 ch 32.

${ }^{74}$ P. Spicker, "The devolution of social security benefits in Scotland" (2015) 23 Journal of Poverty and Social Justice 17, p 20.

75 See, for example, N. Sturgeon, "Foreword from the Deputy First Minister" in Scottish Government, Child poverty strategy for Scotland: our approach 2014-2017 (Edinburgh: Scottish Government, 2014) 3.

76 In particular, the focus was on mitigating the impact of the spare room subsidy, or 'bedroom tax', through increased funding for DHPs, and on setting up the Scottish Welfare Fund to replace the national Social Fund: see K. Berry, Discretionary housing payments (SPICe briefing 14/17, Edinburgh: Scottish Parliament, 2014); Welfare Funds (Scotland) Act 2015 asp 5.

77 G. Scott and S. Wright, "Devolution, social democratic visions and policy reality in Scotland" (2012) Critical Social Policy 440. 
This is a pre-copyedited, author-produced version of an article accepted for publication in the Journal of Social Security Law following editorial review. The definitive published version (Gráinne McKeever, "Legislative scrutiny, co-ordination and the Social Security Advisory Committee: from system coherence to Scottish devolution" (2016) 23(3) JSSL 126) is available online on Westlaw UK or from Thomson Reuters DocDel service.

officials and Ministers, and regular stakeholder visits identify that Scottish specific issues are sought, raised and considered, simultaneously informing the Committee's understanding of Scottish considerations while tailoring the fit of its recommendations to include the Scottish perspective. ${ }^{78}$

Following the 2014 Scottish independence referendum, the Smith Commission set out the proposals for greater devolved powers which had been agreed by the five main political parties in Scotland. ${ }^{79}$ In relation to social security this included a mixture of devolved and reserved responsibilities ${ }^{80}$ and a joint UK-Scottish ministerial working group on welfare reform was created to oversee the transfer. ${ }^{81}$ In Scotland, like Northern Ireland, social security devolution is limited, with a similar profile of policy divergence. Disability and carers feature prominently, as do top-up payments that echo the Northern Ireland focus on mitigations. Operational variations for UC match those for Northern Ireland, as does the plan to mitigate the 'bedroom tax' entirely. The Scottish Welfare Fund has replaced the Social Fund.

Bell has identified that there are "considerable overlaps between the devolved and reserved benefits, which will add significantly to the complexity of an already complex system" and recommended close co-operation between the DWP and its Scottish counterpart. ${ }^{82}$ The Scottish Parliament Devolution (Further Powers) Committee gave

${ }^{78}$ The consideration of Scottish-specific issues is evident in, for example, the Committee's Independent Work Report on localisation; the stakeholder visit to Scotland in 2015, which included meetings with Scottish parliamentary committees, and the Committee's bi-annual stakeholder event for 2016 that was held in Scotland; from private sessions held by the Committee with DWP officials to review the social security issues arising from the Scotland Bill; and from Committee minutes considering a range of Scotland-specific issues from the definition of care-leavers, to the scrutiny of DWP Regulations arising from the impact of the Scottish rate of income tax.

${ }^{79}$ Smith Commission, Report of the Smith Commission for further devolution of powers to the Scottish Parliament (Edinburgh: Smith Commission, 2014), available at https://www.smithcommission.scot. See McKeever, (2015) 22 J.S.S.L. 16-18.

80 The Smith Commission proposed devolving benefits for carers, disabled and sick people, and powers over support for unemployed people, as well the power to create new benefits in areas of devolved responsibilities. UC would remain a reserved benefit, administered and delivered by DWP, with some administrative powers devolved to the Scottish Parliament relating to payment frequency, splitting of payments and housing costs, but not extending to the earnings taper, conditionality and sanctions all of which would remain under the control of the UK parliament. An interim report by the Scottish Parliament's Devolution (Further Powers) Committee in 2015 concluded that the UK government's proposed welfare provisions had not met the spirit and substance of the Commission's recommendations: New Powers for Scotland: An Interim Report on the Smith Commission and the UK Government's Proposals, SP Paper No.720, Session 4, 2015. See McKeever, (2015) 22 J.S.S.L 71.

${ }^{81}$ Scotland Office, Scotland in the United Kingdom: An enduring settlement, Cm.8990, 2014. The Scottish Parliament's Devolution (Further Powers) Committee sets out the trajectory of debate from the Smith Commission to the final version of the Scotland Bill which is recommended to the Scottish Parliament: http://www.scottish.parliament.uk/parliamentarybusiness/CurrentCommittees/97413.aspx. See T. Mullen, "Devolution of Social Security" (2016) 20 Edinburgh Law Review 382 for an overview of the relevant issues.

82 D. Bell, Who will be affected by Scotland's new welfare powers? (London: Centre on Constitutional Change, 2016), available at http://www.centreonconstitutionalchange.ac.uk/publications/reports/who-will-be-affectedscotland's-new-welfare-powers [accessed 4 August 2016] 
This is a pre-copyedited, author-produced version of an article accepted for publication in the Journal of Social Security Law following editorial review. The definitive published version (Gráinne McKeever, "Legislative scrutiny, co-ordination and the Social Security Advisory Committee: from system coherence to Scottish devolution" (2016) 23(3) JSSL 126) is available online on Westlaw UK or from Thomson Reuters DocDel service.

some consideration to the issue of how the social security systems run by both the Scottish and UK Governments would engage with and work with each other, including taking evidence from the Scottish member of the SSAC, Jim McCormick, who emphasised the "need to start thinking about appropriate oversight, scrutiny and transparency arrangements so that ... we have much better machinery for independent and parliamentary oversight." 83 The Committee accepted the point that inter-governmental relations would be crucial to the successful operation of welfare policy in Scotland and the UK, and its interim report recommended:

"[T]hat the principles which will govern the operation of inter-governmental relations with regard to welfare should be placed in any future Bill devolving power in this area ... [T] he Committee expects that this will include the principles via which Parliaments can maintain scrutiny and oversight of the inter-governmental machinery with regard to welfare." 84

The Committee did not explicitly recommend that the SSAC (or any ALB) should have an oversight role in Scotland, and the draft Scotland Bill did not contain any clause to extend the oversight of the SSAC to the devolved social security powers in Scotland. Nor is a role for the SSAC mentioned in the Welfare Reform Committee's report on the delivery of devolved social security services. ${ }^{85}$

The Fiscal Framework for Scotland inevitably dominated much of the discussion on the issues around the Scotland Act 2016,86 focusing on how it would operate alongside the principle of 'no detriment' and how the costs of Scottish policy variations could be calculated, and met. ${ }^{87}$ At the core of much of the debate, however, was how the different benefits and systems would interact with each other. As Spicker notes:

"There is a risk that devolution of benefit systems could produce inequalities and anomalies. There are some inconsistent provisions in the current system, often arising from gaps or overlaps between benefits ... Devolving some benefits and not others creates a potential for generating further anomalies - for example, creating situations where raising benefits in one place led to loss of benefit in another." 88

The potential for anomalies seems greater where there are different ideological or fiscal ambitions driving benefit delivery and design. The need for oversight to scrutinise the

${ }^{83}$ New Powers for Scotland: An Interim Report on the Smith Commission and the UK Government's Proposals (2015) SP Paper No.720, at para. 316. See also para.s 272-273, 310-312.

${ }^{84}$ New Powers for Scotland (2015) SP Paper No.720, para. 328. See also para.s 336, 338-339, making similar recommendations.

85 Welfare Reform Committee, The future delivery of social security in Scotland (2015) SP Paper No.853.

86 The Scotland Bill was introduced in May 2015 and received Royal Assent on 23 March 2016.

87 HM Government and The Scottish Government, The agreement between the Scottish government and the United Kingdom government on the Scottish government's fiscal framework (2016) available at:

https://www.gov.uk/government/uploads/system/uploads/attachment data/file/503481/fisca

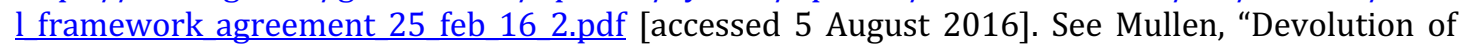
Social Security" (2016) 20 Edinburgh Law Review 382 for further discussion on how Scotland's devolved social security is to be financed.

${ }^{88}$ P. Spicker, "The devolution of social security benefits in Scotland" (2015) 23 Journal of Poverty and Social Justice 17-28, p 22. 
This is a pre-copyedited, author-produced version of an article accepted for publication in the Journal of Social Security Law following editorial review. The definitive published version (Gráinne McKeever, "Legislative scrutiny, co-ordination and the Social Security Advisory Committee: from system coherence to Scottish devolution" (2016) 23(3) JSSL 126) is available online on Westlaw UK or from Thomson Reuters DocDel service.

legislative proposals giving life to potentially conflicting ambitions would also, therefore, seem greater, as would the need to access expert and independent advice to assist in the execution of newly acquired powers. In short, the role of the SSAC in providing independent advice to the Scottish and UK governments to ensure coherence across related benefit systems would seem to be required.

This is all the more necessary in light of the fact that the partially shared competence over social security between the Scottish and Westminster parliaments is further complicated by the Sewel convention. The convention provides an understanding that the UK parliament will not normally legislate on devolved matters without the consent of the devolved legislature, allowing co-ordinated changes to be made to legislation that inevitably touches on both reserved and devolved matters. ${ }^{89}$ Gallagher attributes such value to the fact that "[w]ell established intergovernmental arrangements involved the devolved administration in the preparation of such legislation, and the Scottish Parliament has developed procedures for scrutinising and debating it." 90 The convention is given a statutory footing under section 2 of the Scotland Act 2016, though the context of shared functions relating to social security are seen by Mullen and Craig to increase the potential for conflict over the operation of the convention, to the point where they question the extent to which section 2 will be justiciable. Their particular concern is the lack of clarity over the role of the convention when shared or overlapping competence is at issue:

"notably whether the convention applies when a Bill clearly has a reserved purpose but also has substantial effects upon devolved matters ... [T] he UK government has too much freedom to determine the scope of application of the convention when there ought to be a shared understanding between the UK and the devolved parliaments and executives." 91

The absence of a clear constitutional architecture to ensure a shared understanding and intergovernmental cooperation on social security, returns us once again to the potential to enable independent oversight of the whole system.

During the Committee debates by the House of Lords, an amendment to the Scotland Bill was proposed by Lord Kirwood to extend the role of the SSAC in relation to devolved social security issues in Scotland.92 Pointing to the SSAC's parallel role over devolved social security issues in Northern Ireland, and echoing the original rationale for the SSAC's creation, Kirkwood questioned why the government was not making similar provision for Scotland:

"It is ... essential to have a single statutory independent UK body that can provide oversight ... of the implications of the way the exercise of the fully devolved powers in Scotland and Northern Ireland are impacting on the

89 J.D. Gallagher, All aboard the constitutional express? Where is the Scotland Bill taking the UK? (Oxford: Nuffield College, 2015).

${ }_{90}$ Gallagher, All aboard the constitutional express? (Oxford: Nuffield College, 2015).

$91 \mathrm{~T}$. Mullen and S. Craig, The Immigration Bill, reserved matters and the Sewel convention (15 April 2016) Scottish Constitutional Futures Forum, at http://www.scottishconstitutionalfutures.org/OpinionandAnalysis/ViewBlogPost/tabid/1767/a rticleType/ArticleView/articleId/6959/Tom-Mullen-and-Sarah-Craig-The-Immigration-BillReserved-Matters-and-the-Sewel-Convention.aspx, [accessed 5 August 2016].

${ }_{92}$ HL Debs, Vol.769, Col. 98, 22 February 2016. 
This is a pre-copyedited, author-produced version of an article accepted for publication in the Journal of Social Security Law following editorial review. The definitive published version (Gráinne McKeever, "Legislative scrutiny, co-ordination and the Social Security Advisory Committee: from system coherence to Scottish devolution" (2016) 23(3) JSSL 126) is available online on Westlaw UK or from Thomson Reuters DocDel service.

effectiveness and coherence of the social security system across the whole of the United Kingdom." 93

The government's response was to confirm its position that the SSAC's role would remain unchanged:

"Once legislative competence has been given to the Scottish Parliament it may, if it wishes, put in place separate scrutiny bodies to consider legislative proposals made by the Scottish Government within the scope of the legislative competence and report back to Scottish Ministers. It is for this reason that we do not support [the amendment] which seeks to change the role of the SSAC to give it a duty to advise Scottish Ministers. We would of course want to put in place arrangements to facilitate information and co-operation between the two Governments." 94

Kirkood's amendment was withdrawn. A further amendment was then moved by the government to confirm that the SSAC cannot give advice to Scottish Ministers on those benefits for which the Scottish Parliament has legislative competence, and that Scottish Ministers will not be able to refer draft regulations to the SSAC for consideration. ${ }^{95}$

Little insight is provided by this response into why the role of SSAC could, or would not be extended. There is no indication of how Kirkwood's amendment would be given effect. The statutory appointment of the Northern Ireland SSAC member is done in consultation with the Northern Ireland department, but the appointment is made by the UK Minister. ${ }^{96}$ It is not possible to identify from the Committee stage debates whether similar arrangements were in mind for Scotland, or whether they would be politically acceptable, or whether the UK government wished to avoid the SSAC acting as a melting pot for the consideration of potentially conflicting policy objectives in draft legislative form. If devolved social security legislation from Scotland were within the SSAC's remit the potential would arise for devolved policies to have an impact on reserved ones, giving the Committee the option to consider comparative approaches to social security objectives, and creating the possibility that the Committee might favour - and recommend - the Scottish rather than Westminster approach, embodying a form of competitive federalism. This would be a different approach than the current cooperative model that Northern Ireland policy has mimicked, where the dominant practice has been for central policy to dictate regional implementation. ${ }^{97}$ There may be some historical echoes of the wish to keep a more politically united Scotland at greater arms length in order to limit devolutionary demands. Regardless of the reason, however, the outcome for the SSAC is now clear.

\footnotetext{
${ }_{93}$ HL Debs, Vol.769, Col.98, 22 February 2016.

${ }^{94}$ Lord Dunlop, Scotland Office, HL Debs, Vol.769, Col.104, 22 February 2016.

${ }^{95}$ Section 33 Scotland Act. The provision also applies to the Industrial Injuries Advisory Council.

${ }^{96} \mathrm{An}$ equivalent non-statutory arrangement applies to the Scottish and Welsh appointments to the SSAC.

${ }^{97}$ In principle, however, there is nothing (other than cost) to prevent Northern Ireland pursuing policy innovations as long as the required consultation takes place. The SSAC would then have to scrutinise these legislative proposals which might in turn influence developments in UK policy. If McLaughlin [2016] NIQB 11 is upheld on appeal then the Northern Ireland Assembly will have to amend the Pensions Act (NI) 2015 because of non-compliance with art 14/art 8 ECHR regardless of whether Parliament chooses to amend the equivalent Pensions Act 2014.
} 
This is a pre-copyedited, author-produced version of an article accepted for publication in the Journal of Social Security Law following editorial review. The definitive published version (Gráinne McKeever, "Legislative scrutiny, co-ordination and the Social Security Advisory Committee: from system coherence to Scottish devolution" (2016) 23(3) JSSL 126) is available online on Westlaw UK or from Thomson Reuters DocDel service.

\section{Options for the future?}

The oversight of UK-wide social security provisions remains within the remit of the SSAC, as does the interaction of devolved provision in Northern Ireland with the provisions in Britain. What is absent however, is oversight of how devolved Scottish provision interacts with social security provision in other parts of the UK, for claimants whose geographical circumstances place them at the centre of this overlap gap. The Scottish issue remains a live interest because the out-workings of devolving social security powers to Scotland are not yet clear, including how related areas will be impacted, such as dispute resolution and tribunal appeals. ${ }^{98}$ In particular, it is not clear what the potential consequences are where policy changes are made by either government. ${ }^{99}$ There is a lack of constitutional clarity on whether the Scotland Act 2016 resolves the questions raised by the Sewel convention as to whether or when the UK parliament can legislate on issues that impact on devolved provision. ${ }^{100}$ It is not clear whether there are adequate intergovernmental mechanisms in place to deal with connected social security issues. And further uncertainty remains over whether the Strathclyde review will be implemented, which would reduce the scope for reviewing regulations in Parliament, making the SSAC's role even more critical as the only substantial review mechanism.

The devolutionary arrangements for social security have been created on an ad hoc, politically reactive basis. The Constitution Select Committee recognises that a fragmented welfare system is the nature of devolution but highlights the constitutional complexity caused by such an asymmetrical system, and laments the absence of a principled approach to devolution to date. ${ }^{101}$ Given the (rhetorically) different drivers for social security policy north and south of the Scottish border, 102 it is important to

\footnotetext{
${ }^{98}$ See Mullen, "Devolution of Social Security" (2016) 20 Edinburgh Law Review 382. The need for coherence might be more urgent if Scotland were to emulate the tendency for sub-state regions in asymmetric devolution settlements to seek to increase their powers over time: see B. Giordano and E. Roller, 'Té para todos? A comparison of the processes of devolution in Spain and the UK' (2004) 36 Environment and Planning 2163.

${ }^{99}$ Evidence to the Constitution Select Committee identifies that the Scotland Act 2016 does not make provision for what happens if there is political disagreement that results in stalemate, and suggests that, on the basis of the experience of Northern Ireland, HM Treasury may decide to reduce the block grant for welfare spending, effectively creating a financial veto over conflicting policies: Constitution Select Committee, The Union and devolution: 10 th report of session 2015-16 (2016) HL Paper No. 149, Mark Durcan MP, question 310, available at http://data.parliament.uk/writtenevidence/committeeevidence.svc/evidencedocument/constit ution-committee/the-union-and-devolution/oral/28313.html [accessed 5 August 2016]

100 The implication is that if the UK parliament is legislating on a devolved social security matter that would normally fall outside the SSAC's remit, the UK parliamentary legislation may then fall within SSAC's remit.

${ }^{101}$ In particular the Committee highlights the difficulties faced by civil servants in reconciling conflicting priorities between devolved and central government policies. Among its recommendations are the need to consider formal structures to manage intergovernmental relations in social security and tax policy, and to create departmental concordats to set out how devolved administrations are to be consulted on the impact of changes to UK government policy: Constitution Select Committee, The Union and devolution (2016) HL Paper No. 149.

$102 \mathrm{~N}$. McEwen, "The territorial politics of social policy development in multilevel states" (2005) 15 Regional and Federal Studies 537; G. Mooney and G. Scott, "The 2014 Scottish independence debate: questions of social welfare and social justice" (2015) 23 Journal of Poverty and Social Justice 5 .
} 
This is a pre-copyedited, author-produced version of an article accepted for publication in the Journal of Social Security Law following editorial review. The definitive published version (Gráinne McKeever, "Legislative scrutiny, co-ordination and the Social Security Advisory Committee: from system coherence to Scottish devolution" (2016) 23(3) JSSL 126) is available online on Westlaw UK or from Thomson Reuters DocDel service.

consider what potential options exist to help develop coherence across devolved and reserved social security administrations, even for an interim period. While there is no agreed set of devolutionary principles that can be drawn on here, there are an emerging set of core principles that can guide and evaluate the options for co-ordinated social security oversight, which frame the objective of avoiding unintended, adverse consequences: impartiality that focuses on how the system works rather than on policy development, independence to draw on evidence to identify where claimants may fall between the gaps between the systems, and expertise that enables legislative coherence.

\section{Option 1: do nothing}

The default option is to leave the chips as they have fallen. The UK government explicitly rejected an amendment to include Scotland's devolved social security powers within the SSAC's remit, and so, arguably, that is that. Any developments undertaken by the Scottish government will not change this fact, and the consideration of Scottish perspectives by the SSAC will have to cope with this limitation. The difficulty with option 1 is that it does not progress the oversight required for the divergent and interacting systems; it offers no opportunity to review the coherence in social security provision for claimants moving around the UK and provides no reassurance of extraparliamentary, independent scrutiny.

\section{Option 2: amend the legislation}

There is no obvious legislative impediment to amend the newly created Scotland Act 2016, and (consequentially) the Social Security Administration Act 1992, to expand the SSAC's remit to include devolved Scottish social security powers. While there is much to recommend this option from the perspective of coherence in particular, it is politically untenable and so remains in the realm of idealistic rather than realistic. ${ }^{103}$

\section{Option 3: create a Scottish oversight committee}

This option remains wide open, and was clearly flagged by the UK government as a way for the Scottish government to manage the social security oversight gap. The Scottish government's consultation on its new social security system invites responses to specific questions on independent scrutiny of Scottish social security arrangements and so, politically, option 3 would seem the most viable and has the added advantage of providing an opportunity to consider what such a body might look like. 104

On the assumption that the Scottish government will develop a Scottish social security advisory body, then further variables emerge in relation to its remit and relationship with the SSAC. The most straightforward version of this model might be to create an independent body with no connection to the SSAC, and with a remit to advise only on devolved social security issues. No permissions or cooperation arrangements would be required, and so no negotiation with UK government departments would be required. This was the option recommended by the independent Expert Working Group on Welfare, and indeed the remit proposed for a Scottish Social Security Commission went

103 The political opposition is likely to be held jointly, with the UK government unlikely to be willing to relinquish power here, and the Scottish Government (and Scottish Parliament) also more likely to prefer a separate, made-in-Scotland solution.

${ }^{104}$ Scottish Government, Consultation on Social Security in Scotland (2016), available at https://consult.scotland.gov.uk/social-security/social-security-in-

scotland/consultation/subpage.2016-06-22.9101210037/ [accessed 5 August 2016]. 
This is a pre-copyedited, author-produced version of an article accepted for publication in the Journal of Social Security Law following editorial review. The definitive published version (Gráinne McKeever, "Legislative scrutiny, co-ordination and the Social Security Advisory Committee: from system coherence to Scottish devolution" (2016) 23(3) JSSL 126) is available online on Westlaw UK or from Thomson Reuters DocDel service.

beyond the SSAC's remit to include powers to review the social security system.105 Significantly, however, the recommendation was premised on the working assumption that Scotland would vote to become independent, and so the need to anticipate interaction between devolved and reserved powers did not arise. Such a body could still assess the impact of devolved provision as it interacts with reserved provision but, inevitably, would not have the advantages of insight that the SSAC has access to, without duplicating the work done by the SSAC, and the only power available where reserved and devolved provision conflicts would be to amend the devolved provision rather than seek to influence change through oversight of reserved powers. For these reasons, a more advantageous version might entail a relationship with the SSAC, to facilitate communication on common issues and seek to capitalise on overlaps in Scottish and UKwide expertise. A relationship between a Scottish oversight body and the SSAC might take one of three broad configurations:

\section{Option $3 A$}

This relationship model might seek to emulate the SSAC's relationship with HMRC and HM Treasury which is based on a Memorandum of Understanding that enables the SSAC to discharge non-statutory functions in relation to benefits and tax credits. ${ }^{106}$ In this hypothetical configuration, the SSAC could be given a non-statutory role to provide advice to the Scottish government and be empowered to share this advisory process with the Scottish advisory body. If the hypothetical ideal was stretched to its limit, the Scottish advisory body would have similar powers to advise DWP, and to share its advisory considerations with the SSAC. This model has its limitations in relation to the potential for cultural clashes between governments and/or their advisory bodies, but more significantly it has political limitations given that the UK government blocked an extension of the SSAC's remit on the basis that it was not the SSAC's role to provide advice to Scottish Ministers. ${ }^{107}$ The most far-reaching version of this model also assumes that the Scottish government is keen to reciprocate by submitting its proposals to the SSAC, which may not be wise to assume.

\section{Option 3B}

Alternatively, a formal relationship might seek to have members common to both oversight bodies. One means of achieving this would be to create ex offico membership for each body, so that a member of the SSAC would be entitled to sit on the Scottish body by virtue of their SSAC position, and a reciprocal arrangement would create an ex-officio position on the SSAC for a member of the Scottish body. ${ }^{108}$ This would require political co-operation to secure agreement from the Secretary of State for Work and Pensions that the membership of the SSAC could be extended to include a Scottish advisory body member, or that the customary Scottish appointee would, in practice, be a member of

105 Expert Working Group on Welfare, Rethinking welfare: fair, personal and simple (2014) para. 4.69-4.71, available at http://www.gov.scot/Resource/0045/00451915.pdf [accessed 5 August 2016].

106 The MOU provides that the Committee will provide advice generally, both on its own initiative and at the request of Treasury Ministers and HMT/HMRC officials, on tax credits, child benefit and guardian's allowance and aspects of policy on National Insurance contributions that affect benefit entitlement.

107 The financial out-workings of this obstacle might be that DWP would not want to fund the SSAC to give advice to the Scottish Government, while Scottish Government may not want to contribute to funding the SSAC if it is already funding its own advisory body.

108 There may need to be more than one ex-officio member, given the concerns that a single membership position may not be sufficiently representative. 
This is a pre-copyedited, author-produced version of an article accepted for publication in the Journal of Social Security Law following editorial review. The definitive published version (Gráinne McKeever, "Legislative scrutiny, co-ordination and the Social Security Advisory Committee: from system coherence to Scottish devolution" (2016) 23(3) JSSL 126) is available online on Westlaw UK or from Thomson Reuters DocDel service.

the Scottish advisory body. The political obstacle here is that the Secretary of State's power to appoint a member of the SSAC would be transferred to the Scottish government.

A variation on this shared membership model might be to emulate other UK-wide ALBs, such as the (now defunct) Administrative Justice and Tribunals Council (AJTC). Under the Tribunals, Courts and Enforcement Act 2007, the AJTC and its Scottish and Welsh Committees were required to have some shared membership, transferring the experience and expertise between the national and regional bodies. ${ }^{109}$ Under this statutory framework, the AJTC included Scottish and Welsh members, who then became members of the Scottish and Welsh committees, respectively. The Scottish appointments to the AJTC were made by the Scottish Ministers with the concurrence of the Lord Chancellor and the Welsh Ministers, with equivalent arrangements for the Welsh AJTC members. The Scottish government is not authorised to appoint the Scottish member of the SSAC, and so the AJTC equivalent model for the SSAC would require membership on the Scottish body to be reserved for a SSAC member, in effect enabling the Secretary of State to dictate who would be qualified to assume this position, something which might be politically unpalatable in Scotland. The only difference between this and the ex officio model would be that the latter would allow the Scottish government's appointee to serve on the SSAC, creating a greater degree of reciprocation.

\section{Option $3 C$}

Finally, an informal relationship between the two advisory bodies could be created, with information sharing between each, facilitated through good Chair-to-Chair relationships, visits and presentations by and to each committee. This might be the easiest (political) option to arrange, but its limitation is the reliance on good relations and perceptions of mutuality of benefit and co-operation as the driver, which would require careful management and a high degree of diplomatic skill, and - pragmatically at least - some degree of consent or acquiescence by the Scottish and UK Ministers. The potential for other priorities to take precedence over the management of this informal relationship also creates a risk with this model, and particularly if the arrangement is not seen to develop productive relationships. This model might be the best version of the 'do nothing' approach, so that no formal or statutory changes are made but discussions take place behind the scenes so that communication channels are opened. The statutory remit of the SSAC could be read expansively to enable invitations to be issued to a Scottish oversight body, with visits reciprocated by the SSAC to enable it to understand better the implications of DWP proposals for Scotland. Given the significance of the need for the SSAC to understand these implications, however, a more formal relationship with the Scottish oversight body might be more effective.

The optimal oversight option will be the one that offers closest adherence to the principles of impartiality, independence and expertise, to enable legislative coherence that ensures the divergence between devolved and reserved social security provision does not penalise claimants moving between the different systems. What this means is that a framework is needed to avoid detriment to individual claimants when the

\footnotetext{
${ }^{109}$ Schedule 7. When the AJTC was abolished, the Scottish Committee was replaced by the Scottish Tribunals and Administrative Justice Advisory Committee, established as an interim committee with a lifespan of two years, ending in November 2015. See http://www.adminjusticescotland.com/Remit\%20\&\%20Working\%20Practices.htm [accessed 5 lune 2016] [accessed 5 August 2016].
} 
This is a pre-copyedited, author-produced version of an article accepted for publication in the Journal of Social Security Law following editorial review. The definitive published version (Gráinne McKeever, "Legislative scrutiny, co-ordination and the Social Security Advisory Committee: from system coherence to Scottish devolution" (2016) 23(3) JSSL 126) is available online on Westlaw UK or from Thomson Reuters DocDel service.

decision of one government adversely affects those claiming social security from the other.

\section{Conclusion}

The landscape of social security is constantly changing, but the scale of legislative change in the last 10 years has been substantial, with the underpinning policy rationale shifting further away from insurance based protection to time limited, conditional support.110 The entrenched pattern of providing skeletal primary legislation where political powers are not fully articulated highlights the weakness of parliamentary oversight mechanisms in preventing executive creep into secondary legislation. This is particularly true of social security scrutiny where the pattern is stretched to extend the role of discretionary-based front line decision-making, so that the exercise of executive powers in practice lack the legal certainty that legislation can provide. These oversight problems are further complicated by the inclusion of devolutionary practices, which may interact with, or be absorbed into, central government oversight, but which rely on good intergovernmental mechanisms and constitutional clarity to ensure that power, policy and practice are coherent and not conflicting.

The scrutiny provided by the SSAC helps to address the oversight gaps that inevitably emerge from parliamentary oversight, while bolstering the ability of parliamentary systems to scrutinise more effectively, 111 but new oversight gaps are emerging as a result of devolution. The newest piece in the devolution puzzle is the Scotland Act 2016, devolving some social security powers that will have to work alongside reserved ones. This division of control is not clean cut between Scotland and the UK; the two systems will have to work in harmony with each other so that claimants do not fall between the gaps, but these gaps may not be obvious, emerging instead as consequential and unintended impacts. The potential for this to be realised is greater where the two systems are reviewed independently of each other, and where the opportunity to see the interaction of the whole piece is lost.

The UK government rejected an amendment to the Scotland Bill that would have seen the SSAC's remit extend to advising the Scottish government on devolved social security matters, but the Scottish government has the power to create its own oversight body. The question that arises is whether an oversight body for Scotland's devolved system would adopt a Scotland-only approach or seek to integrate a UK-wide perspective. It would seem an unnecessarily and unfeasibly narrow focus to exclude the wider picture - an argument that applies not just to the Scottish approach but to that of the SSAC as

${ }^{110}$ A. Porter and M. Riddell, "Iain Duncan Smith: my welfare reforms are Beveridge for today, with a hint of Tebbit" (Daily Telegraph, 6 November 2010) http://www.telegraph.co.uk/news/politics/conservative/8114432/Iain-Duncan-Smith-Mywelfare-reforms-are-Beveridge-for-today-with-a-hint-of-Tebbit.html [accessed 5 August 2016]; S.A. Bello, "Social landlords and the courts bear the brunt for welfare reform" (2013) 16 Journal of Housing Law 95; N. Harris, "The transition to universal credit" (2013) 20 JS.S.L. 95.

${ }^{111}$ See for example on the Welfare Reform and Work Bill: Public Bill Committee, 17 September 2015, 6 $6^{\text {th }}$ sitting, Col 255; HL Debs, Vol.768, Col.s 1862 and 1868, 3 Feb 2016; HL Debs, Vol.768, Col.2124, 9 February 2016. 
This is a pre-copyedited, author-produced version of an article accepted for publication in the Journal of Social Security Law following editorial review. The definitive published version (Gráinne McKeever, "Legislative scrutiny, co-ordination and the Social Security Advisory Committee: from system coherence to Scottish devolution" (2016) 23(3) JSSL 126) is available online on Westlaw UK or from Thomson Reuters DocDel service.

well. Formal (and transparent) cooperation between the two bodies, therefore, would seem to be the best, and most feasible option for now, which, over time, could provide further insight into whether an integrated oversight body might ultimately be required.

The SSAC currently operates under a Memorandum of Understanding to provide advice to HMRC on a non-statutory basis. This model incorporates two separate government departments but crucially only one government. The application of this model to devolved oversight requires intergovernmental cooperation that was denied, in principle, through the decision not to extend the SSAC's remit to cover devolved Scottish powers. A 'soft' version of the statutory model might be possible but it relies on assumed co-operation that is not yet evident. At the other end of the scale of possibilities is the behind-the-scenes model, which relies on two oversight committees developing an informal relationship to share information that will assist in their respective oversight roles. The SSAC has good form on this approach, ${ }^{112}$ but there are limitations on what can be delivered by each side in the face of other statutory priorities. A final alternative would integrate the perspectives through shared membership on each oversight body. This could be through an ex-officio position created to allow the SSAC to be represented on the Scottish body, and vice versa, to share expertise between the bodies with the objective of creating greater coherence through independent oversight. Again, political choices would have to be made to facilitate this option, by creating an additional position on the SSAC for a Scottish government appointee, with reciprocation by the Scottish oversight body. The variation on this approach would be to reconfigure the criteria for the Scottish appointment to the SSAC to include membership of the Scottish oversight body, and to reserve a position on the Scottish oversight body for a SSAC member. There is not great deal in practical terms between these last two variations in that each facilitate cross-membership, although the political will to progress either has not yet been tested.

The choice of model is limited but the need for joint oversight remains. If a single oversight body is not possible, then a way forward is required to enable some shared oversight. Social security claimants are often managed by social security legislation to behave in particular ways, and this requires a consistent and coherent message that claimants can understand and respond to. A behavioural incentive to remain only in one part of the UK so as not to fall foul of gaps between devolved systems would seem to run counter to political objectives to 'activate' claimants to support themselves independently. More substantially, claimants who move within the UK, through choice or compulsion, should not be penalised by systems that are unable to work together. Oversight is needed not just to provide expert, independent and impartial advice, but to ensure fairness in the treatment of claimants regardless of their geographical circumstances.

\footnotetext{
${ }^{112}$ See for example M. Betts, (1994) 1 J.S.S.L. 105, p 109: "The Committee rarely has a high profile, except when our advice is controversial and the media preface their reports with 'even the Government's own advisory committee ...'. There is much to be said for working quietly in the background, especially if things nevertheless get done."; G. Saunders, "Reflections on the development and work of the Social Security Advisory Committee" (2007) 15 Benefits 313. See also engagement by the Committee with the Scottish Parliament's Devolution (Further Powers) Committee, 19 February 2015, and the Welfare Reform Committee, 24 March 2015.
} 